\title{
Az étkezési magatartás összefüggése az ételválasztási motivációkkal és egyes személyiségbeli jellemzőkkel középiskolások körében
}

\author{
The correlation of eating behavior with food preference motivation \\ and personality related factors among adolescents
}

\author{
Szerzők: Szabó Katalin ${ }^{\mathrm{a}} \bowtie$, Pikó Bettina ${ }^{\mathrm{b}} \bowtie$ \\ a: SZTE Neveléstudományi Doktori Iskola, Szeged, b: SZTE Magatartástudományi Intézet, Szeged
}

Beküldve: 2017.05.18.

doi: 10.24365/ef.v58i2.152

Bevezetés: Manapság a betegségek megelőzése és az egészség fenntartása az egyik legfontosabb nemzeti és nemzetközi célkitűzés. Erre irányulnak az egészségmagatartással kapcsolatos kutatások, amelyek az egészséges és az egészségtelen életmód szempontjait vizsgálják. Az egészségmagatartáson belül kiemelten fontos a táplálkozás, mivel az elhízás, és az ebből eredő betegségek súlyos terheket jelentenek egyéni és társadalmi szinten egyaránt. A helyes táplálkozási szokásokat már kisgyermekkortól kellene kialakítani, de a serdülőkor a legérzékenyebb időszak, amely során érdemes odafigyelni a megfelelő mennyiségú és minőségú tápanyagbevitelre, tekintettel az ekkor zajló testi és lelki változásokra. Kutatásunkban ezért is túztük ki célul középiskolások táplálkozási szokásainak, magatartásának és motivációinak felmérését. Ezenkívül szintén elemeztük bizonyos személyiségbeli jellemzők (önkontroll, optimizmus/pesszimizmus, énhatékonyság) összefüggését az étkezési magatartással és a motivációkkal.

Módszerek: Vizsgálatunkat egy budapesti szakgimnáziumban végeztük 97 fő bevonásával. A minta 70,1\%-a lány, életkorának átlaga 17,4 év, szórása 1,5 év volt. Az adatgyüjtéshez önkitöltős kérdőívet alkalmaztunk.

Eredmények: Eredményeink azt mutatják, hogy a vizsgált serdülők körében a reggelizés és a családdal töltött étkezések gyakorisága elmarad a várttól. Az étkezési magatartást vizsgálva megállapítható, hogy az optimizmus, az önkontroll, és kisebb mértékben az énhatékonyság, egészségvédő hatásúak a táplálkozás szempontjából, szemben a pesszimizmussal. Az étkezési motivációk eltérnek az egészséges és egészségre kockázatos ételek fogyasztása terén: míg az előbbiek esetében az egészség a fontos szempont, az utóbbiaknál fontosabbak az érzelmi hatások, a szokások, és akár a társadalmi normák, imázs is. A személyiségbeli jellemzők nemcsak az étkezési magatartást, hanem a motivációkat is befolyásolják.

Következtetés: Ezek az eredmények felhasználhatók a fiatalok ételválasztási preferenciáira építő preventív programok kidolgozása során.

Kulcsszavak: étkezési szokások, étkezési magatartás, étkezési motivációk, serdülők

Introduction: Nowadays prevention of disease and maintenance of health are among the most important national and international aims. Research projects of health behavior are focused on examining the aspects of healthy and unhealthy lifestyles. Nutrition is especially an important part of health behavior, because obesity and related diseases are a serious burden at both individual and societal level. The appropriate eating habits should be elaborated as early as from childhood, but adolescence is the most sensitive period when people should pay attention to 
adequate quantity and quality of nutrient intake regarding changes in body and mind. Therefore, in our research we aimed to measure adolescents' eating habits, behavior and motivations. Besides, we also investigated the relationship of some personality variables (self-control, optimism/pessimism, self-efficacy) with eating behavior and motivations.

Methods: Our study was going on with the participation of 97 high school students in Budapest. The mean age of the sample was 17.4 years, standard deviation was 1.5 years, and $70.1 \%$ of the participants were girls. For collecting data we used self-administered questionnaire.

Results: Our results suggest that the frequency of breakfast and eating with the family is less than it has been expected. From the aspect of eating behavior we can assess that optimism, self-control and self-efficacy to a smaller degree have a health protective role in contrary of pessimism. Eating motivations are different in consuming healthy and risky foods: in the case of healthy diet health is the major motivation factor, while behind unhealthy diet affective influences, habits, social norms and image are in the background. Personality related factors may influence not only eating behavior but also motivations.

Conclusion: These results may be used for working out preventive programs based on adolescents' food choice preferences.

Keywords: eating habits, eating behavior, eating motivation, adolescents

\section{BEVEZETÉS}

A fiatalok optimális testi és lelki fejlődéséhez szükségszerű a megfelelő táplálkozás, mégis a gyermekek és serdülők táplálkozási szokásai egyre kedvezőtlenebbek világszerte. ${ }^{1}$ Kamaszkorban a függetlenedés, a kockázatkereső magatartás, illetve a kortársnyomás hatására változhatnak az étkezési szokások. ${ }^{2,3} \mathrm{~A}$ gyorsételek fogyasztása, a rendszertelen étkezések, a szükségtelen fogyókúrák, a felgyorsult életritmus, a média hatásai és az aktuális kulturális társadalmi divathullámok hosszútávon az egészséget is veszélyeztetik. ${ }^{4,5} \mathrm{Az}$ egészségtelen táplálkozásból eredeztethető betegségek, valamint a serdülőkorban zajló testi változások miatt még jobban oda kellene figyelni a megfelelő tápanyagok bevitelére. ${ }^{6} \mathrm{~A}$ táplálkozás minőségének mutatója lehet az étrend összetétele, valamint környezeti szempontból a szülők és a kortársak hatásai. Gyermekkorban a szülők feladata az egészséges ételek és a közös családi étkezések biztosítása. ${ }^{2}$ Később ez a kortárshatásra módosulhat, főként a lányok körében, akik az ételválasztás terén hamarabb önállósodnak. ${ }^{3}$ Ezért is fontos megismernünk a serdülők étkezési szokásait, ételválasztásuk motivációit, illetve a szokásokat befolyásoló pszichológiai tényezőket.

A megfelelő tápanyagszükséglet bevitele terén nagy gondot okoz, hogy sokan nem ismerik az egyes ételek egészségre gyakorolt hatását. Ez a fiatalabbakra még jobban jellemző. Magyarországon különösen magas az egészségtelen táplálkozásból származó betegségek aránya, úgymint az elhízás és az ezzel együtt járó magas vérnyomás és cukorbetegség. ${ }^{7} \mathrm{Ez}$ a tendencia a fiatalok körében is megfigyelhető: a lányok $12 \%$-a és a fiúk $22 \%$-a túlsúlyos, amely a széles körben elterjedt gyorsételek és snackek, valamint a cukros üdítőitalok túlzott fogyasztásának eredménye lehet. ${ }^{4,8}$ Viszont a 15-17 évesek között a másik véglet sem elhanyagolható, a lányok negyede és a fiúk ötöde kórosan sovány, ami a túlzott diétázásra, testképzavarokra és evési zavarokra utal., ${ }^{8,9} \mathrm{~A}$ főétkezések száma és gyakorisága, a reggelizés, az étrend összetétele és a közös családi étkezések meghatározzák a megfelelő étkezési szokásokat, és csökkenthetik a túlsúly kialakulását. A magyar serdülők a nemzetközi átlagot el nem érő aránya reggelizik (48,3\%), illetve a közös családi étkezések száma is alacsony (mindennap: 7,3\%), amely a modellhatás szempontjából hátrányos lehet. ${ }^{2}$ Az egészséges táplálkozással összefüggésben megállapíthatjuk viszont, hogy a fiatalok gyümölcs- és zöldségfogyasztása a nemzetközi átlagnak megfelel, sőt a zöldségfogyasztás mértéke nőtt az elmúlt években. ${ }^{2}$ Az elhízás, a különböző táplálkozási zavarok és azzal kapcsolatos betegségek megelőzéséhez, valamint az egészség fenntartására szolgáló prevenciós programok kidolgozásához fontos tudni azt, hogy az egyének miért választják az adott ételeket, amelyeket fogyasztanak. ${ }^{10} \mathrm{Az}$ étkezés hátterében számos motiváció meghúzódhat az éhségérzeten kívül. 
Ilyen például az étkezés közbeni kellemesség érzése, az étel kinézete és illata. ${ }^{11,12} \mathrm{~A}$ táplálkozási szokásokra nemcsak egyéni, hanem szociális tényezők is hatnak, mint a közös étkezések, amelyek befolyásolhatják az ételeink kiválasztását ${ }^{11}$, valamint a szociális normák és mások elvárásai. ${ }^{13} \mathrm{Az}$ ételválasztási motivációkat befolyásolja az életkor is. Sproesser kutatásaiból az derül ki, hogy míg a harminc évnél idősebbek számára az ételek megválasztásánál fontos a természetesség iránti igény, valamint az ételek egészséges volta, addig a fiatalabbak motivációjában nagyobb súllyal szerepelnek olyan jellemzők, mint a kinézet, az öröm, az étel ára, a tetszés, az éhségérzet, vagy akár a társadalmi normák és az érzelmek. ${ }^{14} \mathrm{~A}$ magyar lakosság étkezési magatartásának a motiváció szempontjából történő szegmentálására használt Holland Evési Kérdőív (DEBQ) alapján a következő klasztereket különítette el egy kutatás: 1) neutrális evők, 2) inger-evők, 3) funkcionális evők, 4) társasági gourmet-k és 5) tudatos evők. Az első három klaszterbe inkább a férfiak, az utolsó kettőbe pedig inkább a nők tartoznak bele. ${ }^{15} \mathrm{~A}$ serdülők motivációi ettől eltérhetnek, ennek megismerésére azonban eddig még nem került sor, ezért is vontuk be vizsgálatunkba ezt a befolyásoló tényezőt.

Az ún. étkezés-szabályozási motivációs elmélet ${ }^{16}$, valamint az étkezéssel összefüggő öndeterminációs elmélet ${ }^{17}$ alapján fontos megismernünk a fiatalok étkezési magatartásának hátterében megbújó pszichológiai tényezőket, amelyek a kontroll és a szándék révén az egészséges vagy éppen egészségtelen ételek irányába motiválhatják őket, sőt, akár diszfunkcionális étkezési szokásokat vagy étkezési zavarokat is előidézhetnek. Korábbi kutatások számos pszichológiai, többek között a személyiséggel összefüggő változóval hozták összefüggésbe az étkezési magatartást. Elemzésünk fókuszába olyan személyiségbeli tényezőket választottunk, amelyeket a szakirodalomban korábban már vizsgáltak, de összefüggésük nem egyértelmű, ezért további vizsgálatokat igényel. Ilyen az önkontroll, ami fontos tényezője lehet az egészséges táplálkozásnak, mivel korlátozni tudja a nem kívánt viselkedést. ${ }^{18}$ Egy kutatásban például kimutatták, hogy a nagyobb mértékű önkontrollal rendelkező serdülők kevesebb pénzt költenek édességre, különböző nassolnivalókra és üdítőitalokra. ${ }^{19}$ Ugyanakkor egy egyetemista mintán végzett vizsgálat azt állapította meg, hogy míg az önkontroll az egészségtelen nassolásban valóban visszatartó erő, a gyümölcs- és zöldségfogyasztással nem függ össze. ${ }^{20}$ Kevés kutatás igazolta az önkontroll és az egészséges étkezés közötti kapcsolatot, kivétel ez alól egy vizsgálat, amely a pozitív egészségmagatartással talált összefüggést, méghozzá a testedzéssel és az egészséges nassolással. ${ }^{21} \mathrm{Az}$ önkontrollal ellentétben az énhatékonyság olyan fontos személyiségbeli jellemző, ami pozitív irányú összefüggést mutat a zöldség- és gyümölcsevéssel ${ }^{22}$, valamint az alacsonyabb zsírtartalmú ételek fogyasztásával. ${ }^{23}$ Szintén meghatározó lehet az optimizmus/pesszimizmus, amelyet meghatározónak találtak egy finn kutatásban, pl. a zöldség- és gyümölcsfogyasztással kapcsolatban: az előző növelte, az utóbbi pedig csökkentette ezen tevékenység gyakoriságát, e mellett a pesszimizmus több egészségtelen ételre csábította a megkérdezetteket. ${ }^{24}$ Ugyanakkor figyelembe kell vennünk a serdülőkorra jellemző irreális optimizmust is, amivel kapcsolatban megállapították, hogy negatívan hat a táplálkozási viselkedésre, mivel az egészségtelen étkezésből eredő kockázatok alulbecslését eredményezheti. ${ }^{25}$ Mindezek alapján úgy döntöttünk, hogy a motivációk mellett ezeket a személyiségbeli jellemzőket is bevonjuk a kutatásba, nem utolsósorban azért is, mert az előbbi tényezőket is befolyásolhatják az étkezési magatartás mellett.

Jelen kutatás egy nagyobb, átfogó vizsgálat pilot elemzését jelenti, ami főként az előzetes tesztelésre és leíró adatok értelmezésére fókuszált. Ennek megfelelően célkitúzéseink a következők voltak: 1) felmérni a középiskolások étkezési szokásait (a reggeli és a családdal együtt történő étkezések gyakoriságát), 2) étkezési magatartását, 3) megismerni az étkezési motivációikat, amelyek szerepet játszanak az ételválasztási preferenciájukban, végül 4) megvizsgálni, hogy az étkezési magatartásuk milyen kapcsolatban áll ezekkel a motivációkkal, valamint egyes személyiségbeli jellemzőkkel, mint az önkontroll, az énhatékonyság és az optimizmus/pesszimizmus. Az utóbbiaknak a motivációkkal való kapcsolatát szintén ellenőriztük.

\section{MINTA ÉS MÓDSZER}

Vizsgálatunkat, amely a fiatalok étkezési szokásait és ételválasztási motivációnak pszichológiai hátterét elemző kutatási projekt pilot vizsgálata, egy budapesti szakgimnázium 9-12. osztályában végeztük 
97 fő bevonásával. A minta életkorának átlaga 17,4 év, szórása 1,5 év volt, az életkori terjedelem 15-20 év közötti. A minta 70,1\%-a lány volt.

Az adatgyűjtéshez önkitöltős kérdőívet használtunk, amely szociodemográfiai és egyéb alapinformációkat tartalmazó kérdéseket, táplálkozással kapcsolatos kérdéseket, valamint a személyiséggel összefüggő változók közül az énhatékonyságot, az optimizmust és pesszimizmust, valamint az önkontrollt mérő kérőíveket foglalta magában.

A szociodemográfiai és egyéb alapinformációkat tartalmazó kérdésekhez tartozott a nem, a kor, az iskola típusa, az évfolyam, az iskolai osztályzatok, a szülők iskolai végzettsége, a szocio-ökonómiai státusz, a szülők családi állapota, és hogy a vizsgálati személy kivel él együtt, a testvérek száma, valamint a testsúly és a testmagasság a testtömegindex kiszámolásához.

A táplálkozási szokások és magatartás felméréséhez a 2014-es HBSC felmérés (Health Behaviour in School-Aged Children) releváns kérdéseit használtuk. ${ }^{2}$ [1.és 2. táblázat]

1. táblázat: Az étkezési szokásokra vonatkozó kérdések I.

\begin{tabular}{|c|c|c|c|c|c|c|}
\hline $\begin{array}{l}\text { „Milyen gyakran szoktál rendesen } \\
\text { reggelizni tanítási napokon?”/hét }\end{array}$ & soha & egyszer & kétszer & háromszor & négyszer & ötször \\
\hline $\begin{array}{l}\text { „Milyen gyakran szoktál rendesen } \\
\text { reggelizni hétvégeken?”/hét }\end{array}$ & \multicolumn{2}{|r|}{ soha } & \multicolumn{2}{|c|}{ csak egyik napon } & \multicolumn{2}{|c|}{$\begin{array}{l}\text { szombaton és vasárnap } \\
\text { is }\end{array}$} \\
\hline $\begin{array}{l}\text { „Milyen gyakran reggelizel együtt } \\
\text { édesanyáddal és édesapáddal?” }\end{array}$ & soha & $\begin{array}{l}\text { ritkábban, } \\
\text { mint hetente }\end{array}$ & $\begin{array}{l}\text { hetente } \\
\text { 1-2-szer }\end{array}$ & $\begin{array}{l}\text { hetente 3-4- } \\
\text { szer }\end{array}$ & $\begin{array}{l}\text { hetente } \\
\text { 5-6-szor }\end{array}$ & mindennap \\
\hline $\begin{array}{l}\text { „Milyen gyakran vacsorázol együtt } \\
\text { édesanyáddal és édesapáddal?” }\end{array}$ & soha & $\begin{array}{l}\text { ritkábban, } \\
\text { mint hetente }\end{array}$ & $\begin{array}{l}\text { hetente } \\
\text { 1-2-szer }\end{array}$ & $\begin{array}{l}\text { hetente 3-4- } \\
\text { szer }\end{array}$ & $\begin{array}{l}\text { hetente } \\
\text { 5-6-szor }\end{array}$ & mindennap \\
\hline
\end{tabular}

Forrás: HBSC $2014^{2}$

2. táblázat: Az étkezési szokásokra vonatkozó kérdések II.

\begin{tabular}{|c|c|c|c|c|c|c|c|}
\hline $\begin{array}{c}\text { „Hetente hány alkalommal fo- } \\
\text { gyasztod a következő ételeket, } \\
\text { italokat?” }\end{array}$ & Soha & $\begin{array}{l}\text { Ritkábban, } \\
\text { mint he- } \\
\text { tente }\end{array}$ & $\begin{array}{l}\text { Hetente } \\
\text { egyszer }\end{array}$ & $\begin{array}{l}\text { Hetente } \\
\text { 2-4-szer }\end{array}$ & $\begin{array}{l}\text { Hetente } \\
\text { 5-6-szor }\end{array}$ & $\begin{array}{l}\text { Minden } \\
\text { nap }\end{array}$ & $\begin{array}{l}\text { Minden } \\
\text { nap több- } \\
\text { ször is }\end{array}$ \\
\hline \multicolumn{8}{|l|}{ Gyümölcs } \\
\hline \multicolumn{8}{|l|}{ Zöldség } \\
\hline \multicolumn{8}{|l|}{ Húsok } \\
\hline \multicolumn{8}{|l|}{ Édességek } \\
\hline Cola és/vagy más üdítőital & & & & & & & \\
\hline Energiaital & & & & & & & \\
\hline
\end{tabular}

Forrás: HBSC $2014^{2}$

A táplálkozási motivációk feltérképezéséhez az Étkezési Motiváció Kérdőívet (továbbiakban TEMS), annak átdolgozott és rövidített változatát alkalmaztuk, amit a szerzők fordítottak magyarra, validálására később kerül majd sor. ${ }^{10,14} \mathrm{~A}$ kérdőív az „azért eszem, amit eszek” álításhoz 45 táplálkozási motivációt sorol fel (például: „....mert megszoktam, hogy ezt eszem"). A válaszok arra vonatkoznak, hogy a megkérdezett választásában milyen gyakran játszanak szerepet ezek a motivációk egy 7 fokú Likert-skálán bejelölve ( 1 = soha, 7 = mindig). A 45 válasz 15 faktorba sorolható: kedvelés, szokások, szükséglet, egészség, kényelem, öröm, tradíció, természetesség iránti igény, szociabilitás, ár, látvány, súly, érzelmi hatás, társadalmi imázs és társadalmi normák.

A pszichológiai változók közül a Scheier és Carver által kidolgozott Life Orientation Test (LOT) nevű skála ${ }^{26}$ magyar verzióját alkalmaztuk az optimizmus és a pesszimizmus mérésére (a magyar mintán mért pszichometriai jellemzőket lásd Bérdi és Köteles kutatásában). ${ }^{27}$ A mérőeszköz összesen 10 állításból épül fel (például: „Bizonytalan időkben a legjobbat várom"), amelyek közül három pozitív, illetve három 
inverz, valamint négy szűrő állítás. Ötpontos válaszadási skálán lehet megjelölni az egyetértés mértékét. A módszer megbízhatósági mutatója a saját mintával, Cronbach alfa =0,82.

Az Énhatékonyság Skála ${ }^{28}$ segítségével került megismerésre az énhatékonyság, annak magyar, validált változatával. ${ }^{29}$ A skála 10 állításból áll (pl. „Mindig meg tudom oldani a nehéz problémákat, ha elég keményen próbálkozom"), amelyekhez tartozó állítások az „egyáltalán nem jellemző” kategóriától a „teljesen jellemző" kategóriáig terjedtek egy négyfokozatú Likert-skálán. Az összesített pontérték 10 és 40 között változhatott, a megbízhatósági együttható, Cronbach alfa $=0,77$ lett. Végül, az ún. Önkontroll skála ${ }^{18}$ tíz itemből áll (pl. „Ellent tudok állni a kísértéseknek"). A skálát szintén a szerzők fordították magyarra. Az állításokkal való egyetértés mértékét ötfokozatú skála (1 = egyáltalán nem jellemző rám... 5 = teljesen jellemző rám) mérte. A skála megbízhatósága, Cronbach alfa = 0,62-nek bizonyult.
Statisztikai elemzéseink leíró statisztikákat és Pearson-féle korrelációt foglaltak magukban, amelyekhez az SPSS for MS Windows Release 22.0.0.0 szoftvert használtunk fel.

\section{EREDMÉNYEK}

A reggeli fogyasztásával kapcsolatban megállapíthatjuk, hogy hétköznaponként a fiatalok 27\%-a soha, míg 44\%-a minden nap reggelizik. Hétvégén 57\%-uk reggelizik szombaton és vasárnap is. A családdal töltött étkezéseket tekintve a serdülők 30\%a soha, 1\%-uk mindig, 36\%-uk heti egyszer-kétszer reggelizik együtt a szüleivel. A vacsorát tekintve 15\%-uk soha, 1\%-uk mindig és legnagyobb arányban, 29\%-uk egyszer-kétszer, valamint 23\%-uk háromszor-négyszer vacsorázik együtt a családjával. [1.,2. és 3. ábra]

\section{1. ábra: A hétköznapi reggelizés gyakorisága}

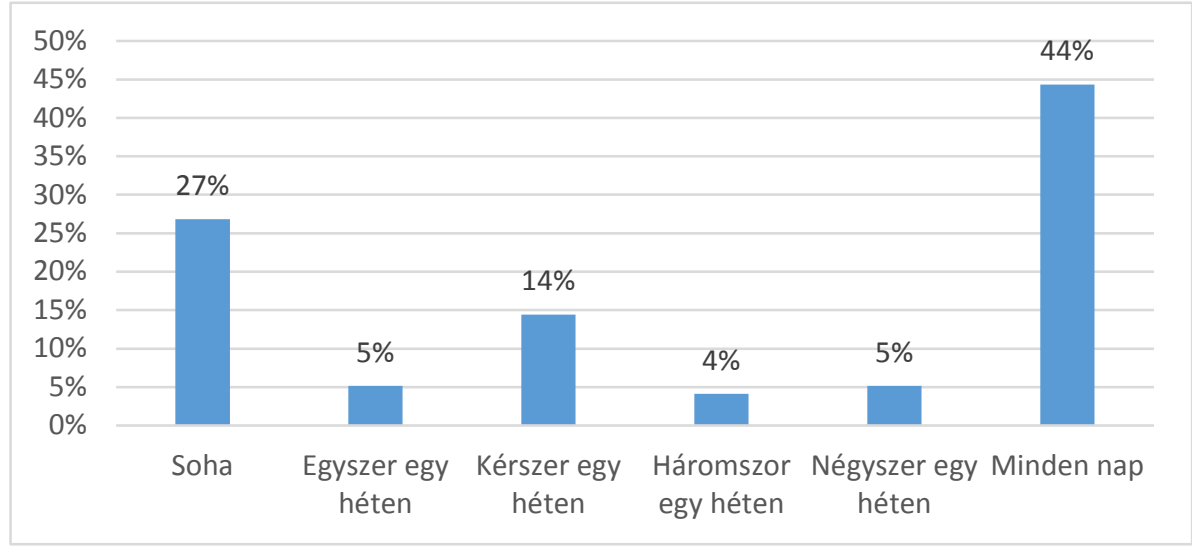

Forrás: Saját szerkesztés

2. ábra: A hétvégi reggelizés gyakorisága

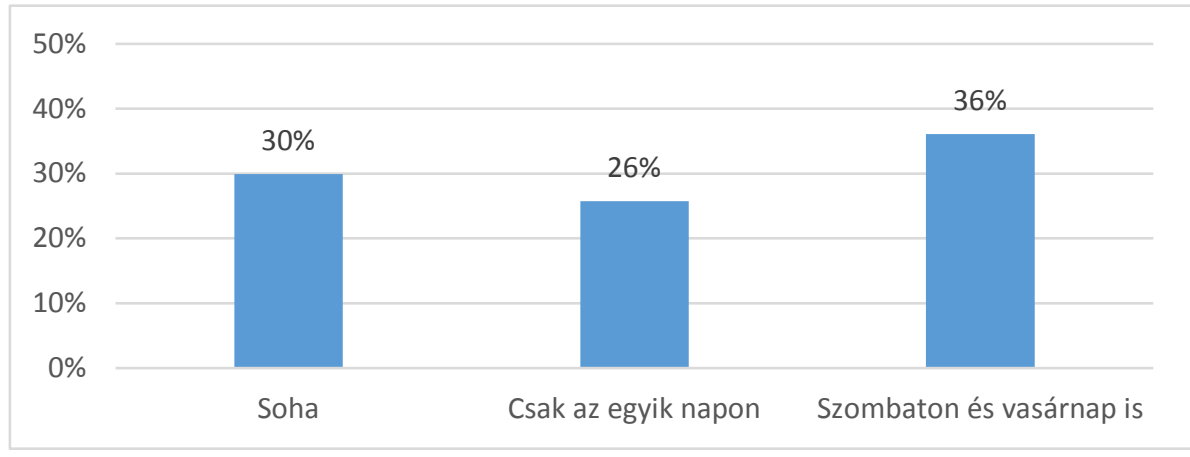

Forrás: Saját szerkesztés 
3. ábra: A családdal való étkezés gyakorisága

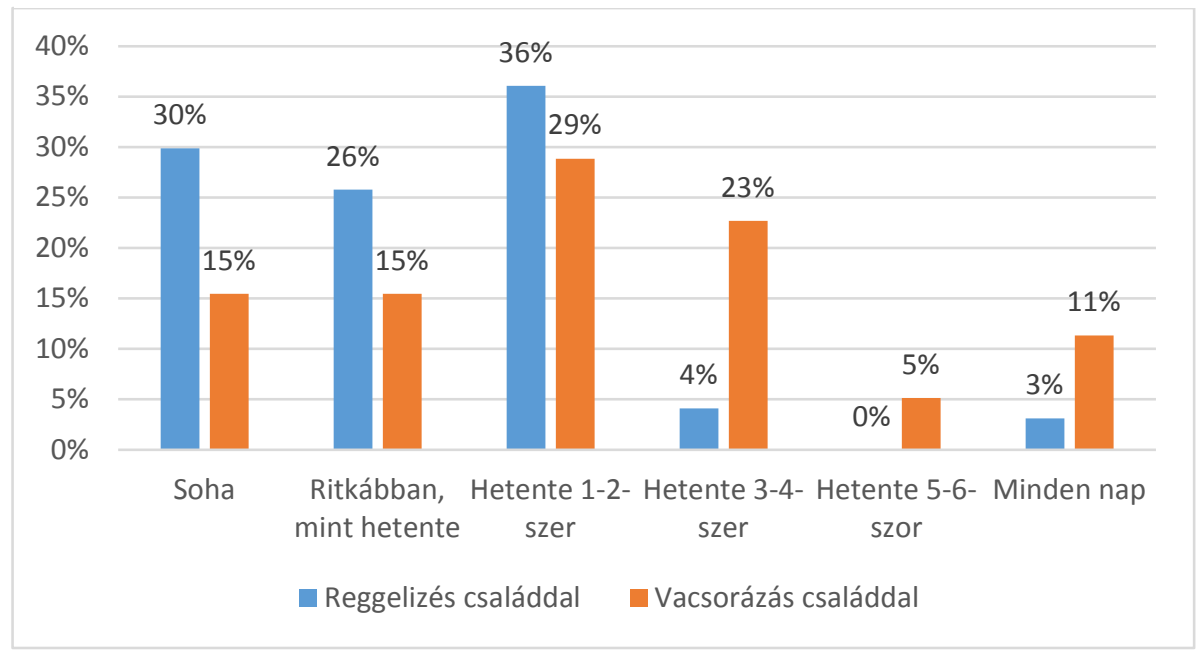

Forrás: Saját szerkesztés

A 4. ábra mutatja az általunk vizsgált étkezési magatartás nyolc tényezőjének gyakoriságát. Látható, hogy gyümölcsöt a vizsgált személyek 30\%-a, zöldséget pedig 38\%-a fogyaszt hetente 2-4 alkalommal. A mindennapos gyümölcs- és zöldségfogyasztás a minta 14\%-ára, illetve 11\%-ára jellemző. A vizsgált személyek 3\%-a viszont soha nem eszik gyümölcsöt és zöldséget. A húsfogyasztás gyakorisága más képet mutat. A vizsgált személyek kis aránya ritkán (soha: 0\%, ritkábban, mint hetente: 4\%, hetente 1szer: 6\%), 90\%-a pedig szinte napi gyakorisággal eszik húst. Az egészségkockázatot jelentő, ezért egészségtelenként jellemezhető ételek nagy részét (kivétel: energiaital) a minta kb. 1/3-a heti 2-4 alkalommal fogyasztja. Az energiaitalt a vizsgált személyek 37\%-a soha, 34\%-a pedig kevesebb, mint heti gyakorisággal választja. Gyorsételeket a vizsgálati személyek 38\%-a ritkábban, mint hetente, addig 28\%-uk hetente 2-4 alkalommal fogyaszt. Nemek közötti szignifikáns különbség csak a gyorsételek fogyasztásánál volt tapasztalható ( $\chi^{2}$-próbával: p 0,001), ami a fiúk gyakoribb választásából adódott.

4. ábra: Az étkezési magatartás tényezőinek gyakorisága

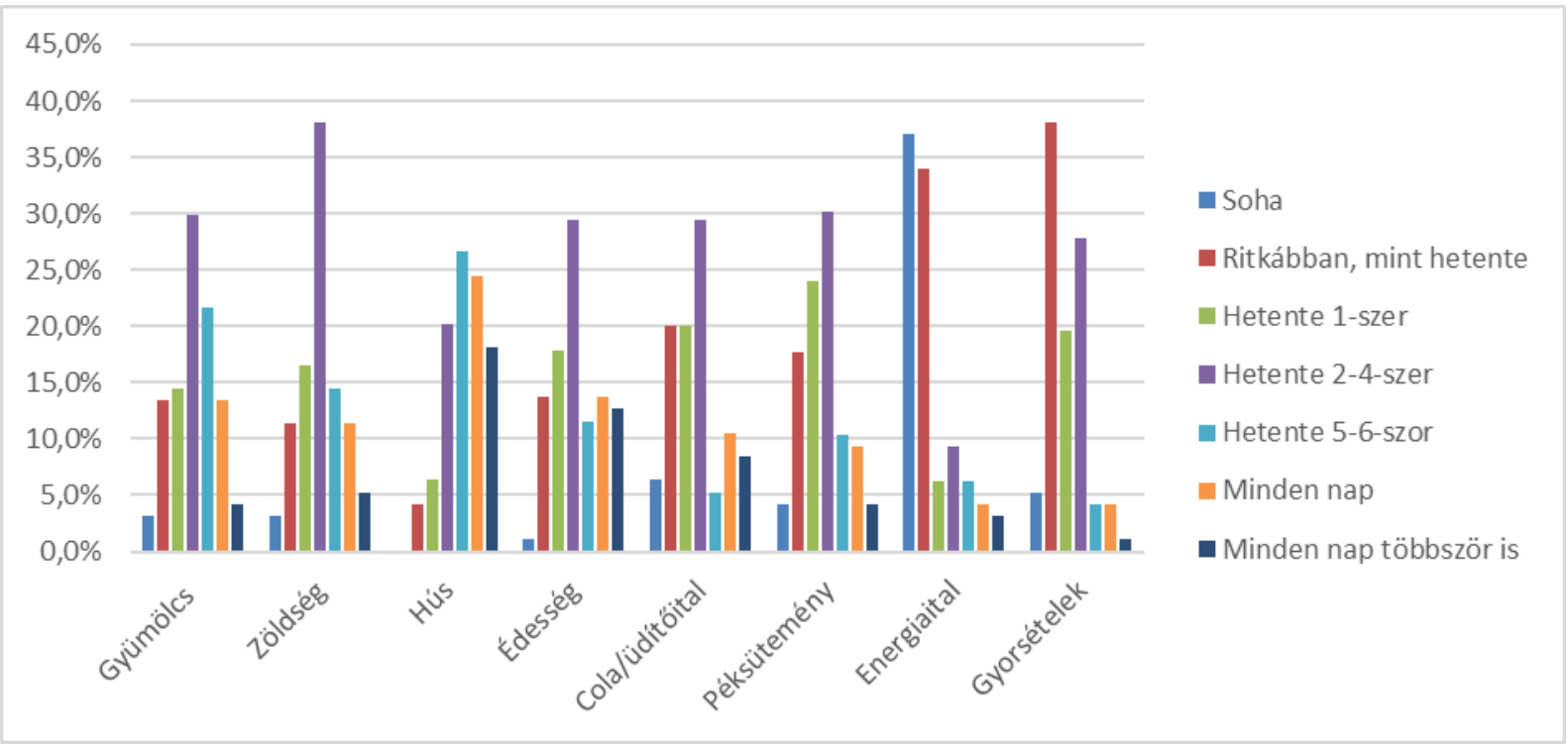

Forrás: Saját szerkesztés 
Statisztikai elemzésünk során összevetettük a pszichológiai tényezők és a táplálkozási magatartás közötti kapcsolatot is. [3. táblázat] Eredményül azt kaptuk, hogy bár a kapcsolat elég gyenge, a pesszimizmus hajlamosíthat az édességek, az energiaitalok és a gyorsételek fogyasztására. Az optimizmus viszont pozitív irányú szignifikáns kapcsolatot mutat a zöldség- és gyümölcsfogyasztással, valamint negatív irányú szignifikáns kapcsolatot az édességek, a Cola/üdítőital, valamint a gyorsételek fogyasztásával. Az énhatékonyság a zöldségfogyasztással mutat pozitív kapcsolatot. Végül az önkontrollal kevésbé rendelkezők többet fogyasztanak a cukros üdítőitalokból, energiaitalokból, valamint gyorsételekből.

3. táblázat: Az étkezési magatartás összetevőinek és a személyiségbeli jellemzőknek az összefüggése

\begin{tabular}{|c|c|c|c|c|}
\hline & Pesszimizmus & Optimizmus & Énhatékonyság & Önkontroll \\
\hline Gyümölcs & $-0,13$ & $0,21^{*}$ & 0,16 & 0,13 \\
\hline Zöldség & $-0,07$ & $0,20 *$ & $0,23^{*}$ & 0,10 \\
\hline Hús & 0,19 & $-0,19$ & 0,05 & $-0,12$ \\
\hline Édesség & $0,28 * *$ & $-0,32 * *$ & $-0,13$ & $-0,18$ \\
\hline Cola/üdítőital & 0,14 & $-0,21^{*}$ & 0,03 & $-0,22^{*}$ \\
\hline Péksütemény & 0,12 & $-0,06$ & $-0,02$ & $-0,05$ \\
\hline Energiaital & $0,24^{*}$ & $-0,21^{*}$ & 0,14 & $-0,37 * *$ \\
\hline Gyorsételek & $0,30 * *$ & $-0,34 * *$ & $-0,14$ & $-0,30 * *$ \\
\hline
\end{tabular}

Megjegyzés: Pearson-féle korrelációs együttható: ${ }^{*} p<0,05{ }^{* *} p<0,01$

Forrás: Saját szerkesztés

Ezek után az étkezési motivációk sorrendjét állítottuk fel az alskálák standardizált átlagértékei és szórásai alapján abból a szempontból, hogy melyek azok a motivációk, amelyek a legjellemzőbbek a mintára, vagyis, hogy az egyének miért eszik azt, amit esznek. Az 5. ábrán látható, hogy kedvelésből és szükséglet miatt fogyasztják a vizsgált személyek leginkább az általuk kiválasztott ételeket. Ezeket követi az öröm, valamint a kényelmi szempont. Legkevésbé motiváló tényezők a társadalmi imázs és a társadalmi normák.

\section{5. ábra: Az étkezési motiváció kérdőív (TEMS) alskáláinak standardizált átlagai}

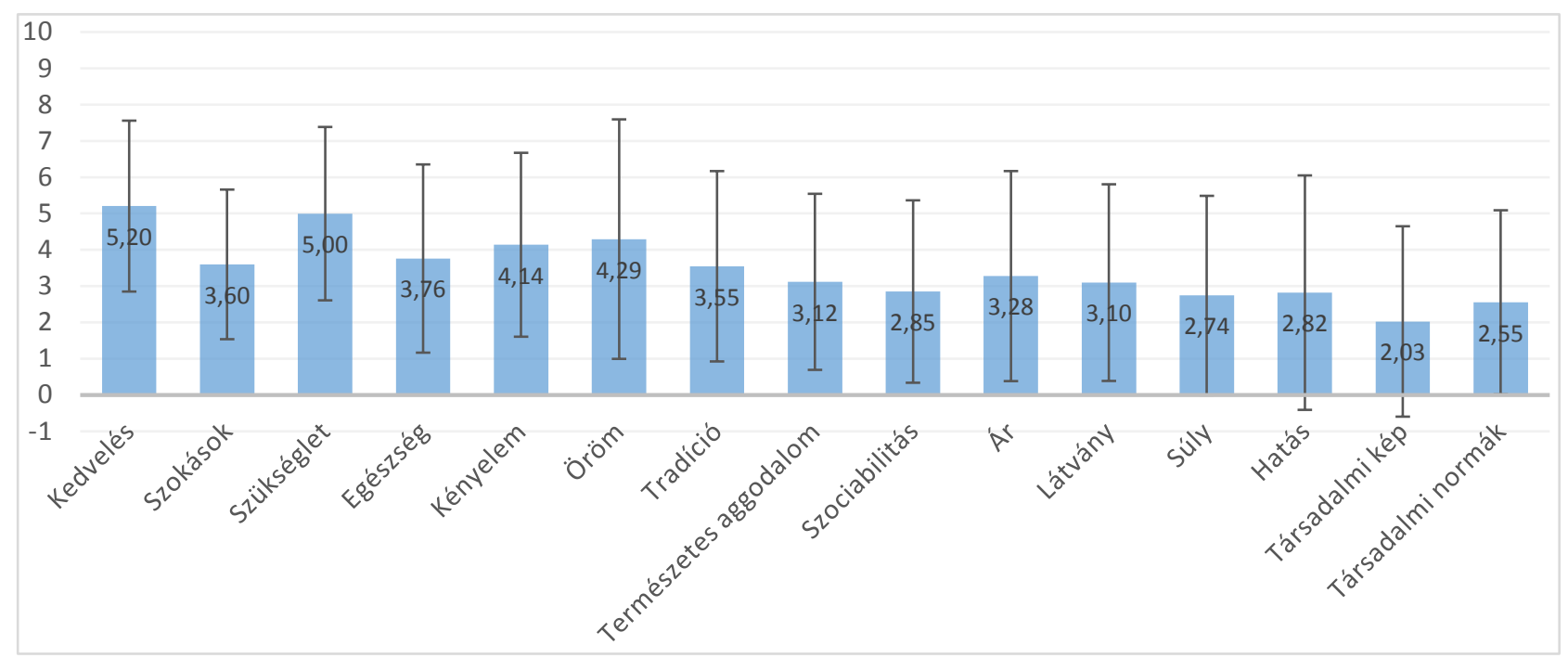

Megjegyzés: 95\%-os megbízhatósági sávokkal Forrás: Saját szerkesztés 
Az étkezési motivációkat nemcsak preferencia-sorrend szerint, hanem az étkezési magatartással öszszefüggésben is elemeztük. [4. és 5. táblázat] A gyümölcsfogyasztással kapcsolatban fontos az egészség, mint motiváció, míg a zöldségfogyasztással kapcsolatban a szokások motivációja. A húsfogyasztás számos motivációval mutatott pozitív kapcsolatot, mint a kedvelés, a szükséglet, a kényelem, az öröm és az érzelmi hatás. Hasonlóan sokféle motivációs kapcsolat igazolható az édességfogyasztás vonatko- zásában is, így a kényelem, a látvány, az érzelmi hatás, míg negatív a kapcsolat a súly motivációval, valamint a természetesség iránti igénnyel. Az egészségre kockázatos ételek és italok (Cola/üdítő-, energiaital-, péksütemény és gyorsételfogyasztás) pozitív kapcsolatban állnak a kedvelés, a szokások, a kényelem, az öröm, a tradíció, a szociabilitás, a látvány, az érzelmi hatás, a társadalmi imázs és a társadalmi normák motivációkkal, illetve negatív kapcsolatban az egészség és a súly motivációkkal.

4. táblázat: Az étkezési motiváció és az étkezési magatartás kapcsolata I.

\begin{tabular}{|l|c|c|c|c|}
\hline & Gyümölcs & Zöldség & Hús & Édesség \\
\hline Kedvelés & $-0,11$ & 0,02 & $0,25^{*}$ & $0,27^{* *}$ \\
\hline Szokások & $-0,06$ & $-0,21^{*}$ & 0,18 & 0,16 \\
\hline Szükséglet & 0,19 & 0,12 & $0,24^{*}$ & 0,15 \\
\hline Egészség & $0,33^{* *}$ & 0,18 & 0,20 & $-0,15$ \\
\hline Kényelem & $-0,09$ & $-0,11$ & $0,23^{*}$ & $0,29^{* *}$ \\
\hline Öröm & $-0,12$ & 0,03 & $0,21^{*}$ & 0,20 \\
\hline Tradíció & $-0,08$ & $-0,11$ & 0,03 & 0,03 \\
\hline Természetesség iránti igény & 0,03 & 0,01 & 0,14 & $-0,23^{*}$ \\
\hline Szociabilitás & $-0,102$ & $-0,19$ & 0,01 & 0,02 \\
\hline Ár & $-0,084$ & $-0,15$ & $-0,01$ & 0,08 \\
\hline Látvány & $-0,082$ & $-0,11$ & 0,09 & $0,43^{* *}$ \\
\hline Súly motiváció & 0,091 & 0,01 & $-0,02$ & $-0,24^{*}$ \\
\hline Érzelmi hatás & $-0,025$ & $-0,10$ & $0,21^{*}$ & $0,26^{*}$ \\
\hline Társadalmi imázs & $-0,068$ & $-0,06$ & 0,01 & 0,04 \\
\hline Társadalmi normák & $-0,079$ & $-0,20$ & 0,01 & 0,14 \\
\hline
\end{tabular}

Megjegyzés: Pearson-féle korrelációs együttható: ${ }^{*} p<0,05 * * p<0,01$

Forrás: Saját szerkesztés

5. táblázat: Az étkezési motiváció és az étkezési magatartás kapcsolata II.

\begin{tabular}{|l|c|c|c|c|}
\hline & Cola/üdítöital & Energiaital & Péksütemény & Gyorsétel \\
\hline Kedvelés & $0,29^{* *}$ & 0,08 & 0,05 & $0,22^{*}$ \\
\hline Szokások & $0,24^{*}$ & 0,16 & $0,24^{*}$ & $0,33^{* *}$ \\
\hline Szükséglet & 0,14 & 0,09 & 0,11 & 0,06 \\
\hline Egészség & $-0,30^{* *}$ & $-0,17$ & $-0,01$ & $-0,27^{* *}$ \\
\hline Kényelem & 0,18 & 0,13 & $0,21^{*}$ & $0,37^{* *}$ \\
\hline Öröm & 0,07 & $-0,01$ & 0,16 & $0,20^{*}$ \\
\hline Tradíció & 0,01 & 0,12 & $0,29^{* *}$ & 0,14 \\
\hline Természetesség iránti igény & $-0,15$ & $-0,19$ & 0,01 & $-0,13$ \\
\hline Szociabilitás & $-0,10$ & 0,17 & $0,27^{* *}$ & $0,33^{* *}$ \\
\hline Ár & 0,02 & 0,08 & 0,17 & 0,16 \\
\hline Látvány & $0,28^{* *}$ & $0,27^{* *}$ & $0,28^{* *}$ & $0,44^{* *}$ \\
\hline Súly motiváció & $-0,38^{* *}$ & $-0,16$ & $-0,07$ & $-0,21^{*}$ \\
\hline Érzelmi hatás & $0,22^{*}$ & 0,14 & $0,24^{*}$ & $0,24^{*}$ \\
\hline Társadalmi imázs & $-0,07$ & 0,06 & $0,21^{*}$ & $0,24^{*}$ \\
\hline Társadalmi normák & $-0,02$ & 0,11 & $0,24^{*}$ & $0,28^{* *}$ \\
\hline
\end{tabular}

Megjegyzés: Pearson-féle korrelációs együttható: ${ }^{*} p<0,05{ }^{*}{ }^{*} p<0,01$

Forrás: Saját szerkesztés 
Végül, a 6. táblázat az étkezési motivációk és a személyiségbeli jellemzők közötti kétoldalú kapcsolatokat jelző korrelációs együtthatókat tartalmazza. A pesszimizmus leginkább a kedvelés, a szokások, a kényelem, a látvány, az érzelmi és társas befolyások (pl. szociabilitás, társadalmi normák, tradíciók) irányába mozdítja el az étkezési preferenciákat. Ezzel szemben az optimizmus összefügg az egészségmotivációval, és inkább ellene megy a kényelemnek, a szokásoknak, a látványnak, az érzelmi hatásoknak és társadalmi normáknak, sőt még akár az árnak is. Ehhez hasonló szerepe van az önkontrollnak, ami negatív összefüggést mutat a kényelemmel, a kedveléssel, az örömmel, a látvánnyal, az érzelmi hatással, az árral, és a társas befolyást jelző motivációs mutatókkal (pl. szociabilitás, társadalmi imázs és norma, szokások, tradíciók), ugyanakkor nem mutat kapcsolatot az egészségmotivációval. Végül, az énhatékonyság az egészségmotivációval (pozitívan) és a szociabilitással (negatívan) korrelál.

6. táblázat: Az étkezési motiváció és a személyiségbeli jellemzők kapcsolata

\begin{tabular}{|c|c|c|c|c|}
\hline & Pesszimizmus & Optimizmus & Énhatékonyság & Önkontroll \\
\hline Kedvelés & $0,21^{*}$ & $-0,13$ & $-0,07$ & $-0,27 * *$ \\
\hline Szokások & $0,32^{* *}$ & $-0,20 *$ & $-0,11$ & $-0,32 * *$ \\
\hline Szükséglet & 0,03 & 0,09 & $-0,13$ & $-0,13$ \\
\hline Egészség & $-0,12$ & $0,22^{*}$ & $0,22 *$ & 0,19 \\
\hline Kényelem & $0,36 * *$ & $-0,23^{*}$ & $-0,14$ & $-0,43 * *$ \\
\hline Öröm & 0,09 & $-0,08$ & $-0,06$ & $-0,21 *$ \\
\hline Tradíció & $0,29 * *$ & $-0,22^{*}$ & $-0,15$ & $-0,21^{*}$ \\
\hline Természetesség iránti igény & 0,02 & 0,05 & 0,15 & 0,05 \\
\hline Szociabilitás & $0,31 * *$ & $-0,24^{*}$ & $-0,23^{*}$ & $-0,37 * *$ \\
\hline Ár & $0,42 * *$ & $-0,30 * *$ & $-0,09$ & $-0,42 * *$ \\
\hline Látvány & $0,49 * *$ & $-0,38 * *$ & $-0,09$ & $-0,55 * *$ \\
\hline Súly motiváció & 0,06 & 0,01 & $-0,05$ & $-0,02$ \\
\hline Érzelmi hatás & $0,41 * *$ & $-0,31 * *$ & $-0,19$ & $-0,34 * *$ \\
\hline Társadalmi imázs & 0,16 & $-0,06$ & $-0,05$ & $-0,24 *$ \\
\hline Társadalmi normák & $0,41 * *$ & $-0,33 * *$ & $-0,03$ & $-0,34^{* *}$ \\
\hline
\end{tabular}

Megjegyzés: Pearson-féle korrelációs együttható: ${ }^{*} p<0,05 * * p<0,01$

Forrás: Saját szerkesztés

\section{KÖVETKEZTETÉS}

Jelen kutatásunkban középiskolások táplálkozási szokásait mértük fel. Ennek érdekében célként tűztük ki étkezési magatartásuk, étkezési motivációik és egyes személyiségbeli jellemzőik felmérését, és ezek összefüggéseinek elemzését.

A reggelizés gyakoriságának szempontjából eredményeink összhangban vannak a HBSC kutatás eredményeivel (30\% soha, 48\%-uk minden nap). Eltérés a hétvégenkénti reggelizésben mutatkozott, ott a HBSC kutatásban résztvevők nagyobb aránya (76\%-a) fogyaszt mindkét nap reggelit. ${ }^{2}$

Az étkezési magatartás szempontjából saját mintánkban a mindennapos zöldség- és gyümölcsfogyasztás $(14 \%, 11 \%)$ a HBSC kutatáshoz $(32 \%, 30 \%)$ képest sokkal kevésbé volt gyakori. Az édességfogyasztásra jellemző, hogy míg a HBSC kutatás alapján a fiatalok közel harmada fogyaszt édességet mindennap, addig a saját mintánkban ez az arány $13,7 \%$ volt.

A személyiségbeli jellemzők közül saját kutatásunk is megerősítette azt az eredményt, hogy a nagyobb énhatékonyságú fiatalok több zöldséget fogyasztanak. ${ }^{22} \mathrm{Az}$ irreális optimizmusnak az egészségtelen táplálkozás kockázatait alulbecslő hatását ${ }^{25}$ vizsgálatunkban nem tapasztaltuk, ellenben az optimistább serdülők több zöldséget, és kevesebb édességet, üdítőitalt és gyorsételt fogyasztottak, hasonlóan a korábbi, finn vizsgálathoz. ${ }^{24} \mathrm{Az}$ önkontroll tekintetében eredményeink is tükrözik, hogy az alacsonyabb önkontrollal rendelkezők, hasonlóan 
korábbi vizsgálatokhoz ${ }^{22}$, több egészségre kockázatos ételt és italt fogyasztanak. Erre a pesszimizmus is hajlamosit. ${ }^{24}$

Az étkezési motivációk jellegzetes képet mutatnak. A gyümölcsfogyasztásnál egyértelmúen az egészségmotiváció, míg a zöldségeknél a szokások, valószínúleg az otthoni étkezések jellege a meghatározó. A húsfogyasztásnak viszont az adatok szerint meglehetősen nagy hagyománya lehet a fiatalok körében is, hiszen azon felül, hogy a motivációk között szerepel a szükséglet, a kényelem, jelentős szerepet kap az öröm, a kedvelés és az érzelmi hatások. Mindez azt igazolja, hogy míg a zöldségeket és gyümölcsöket azért fogyasztják, mert megszokták, és mert egészségesnek vélik, a húsételeket valóban kedvelik. Az édességfogyasztásnál a kedvelés, a látvány és egyéb érzelmi hatások meghatározóak, viszont itt a súly és az egészség, mint motiváció negatív előjellel szerepelnek, csakúgy, mint a gyorsételeknél és az üdítőitalok fogyasztásánál, arra utalva, hogy a fiatalok ezzel a szemponttal nem foglalkoznak. A gyorsételek fogyasztásánál az érzelmi hatások mellett a szociabilitás, a társadalmi normák és imázs is szerepet játszik, ami a gyorséttermek kínálatának (pl. hamburger) szimbólumértékére is utal. ${ }^{30} \mathrm{~A}$ fiatalok számára ezért is vonzó. A péksüteményekkel kapcsolatban pedig ki kell emelni a látvány és egyéb érzelmi hatások mellett a szokások, a tradíció és társadalmi normák mellett a szociabilitás szerepét is, hiszen ez olyan étel, amit a barátok gyakran együtt fogyasztanak. Ez egyébként a gyorséttermi ételekre is igaz.

Ki kell még emelni a motivációk és a személyiségbeli jellemzők együttes szerepét is, amit előző kutatások javasoltak. ${ }^{14,16,17} \mathrm{Az}$ énhatékonyság és az optimizmus egyértelműen az egészségmotivációt erősíti, hasonlóan korábbi vizsgálatokhoz. ${ }^{10,14,24}$ Ezzel szemben az önkontroll nem mutat összefüggést az egészségmotivációval, ellenben erősíti a lemondást olyan szokásokról, amelyek esetleg az egészségre kockázatos ételek irányába mozdítanák el az étkezési preferenciát (pl. édességek). Ez az eredmény megerősíti az önkontrollnak, mint személyiségjellemzőnek azt a szerepét, ami elsősorban a viselkedési gátlásban, azaz a nemkívánatos étkezéstől való tartózkodásban nyilvánul meg. ${ }^{20}$ Erre az étkezési magatartás és a pesszimizmus közötti kapcsolatok is utalnak.
Összefoglalásként elmondhatjuk, hogy vizsgálatunkban az étkezési szokások leíró adatai nagyrészt összhangban voltak az eddigi eredményekkel. Megállapíthatjuk, hogy a serdülők reggeli fogyasztását és a családdal való együtt töltött étkezések számát ösztönözni kellene, mivel ezek szükségszerúek lennének az egészséges táplálkozási magatartás és az egészséges életmód kialakításához, továbbá a társas kapcsolatok és készségek fejlesztéséhez. ${ }^{2,31} \mathrm{Az}$ étkezési magatartásra vonatkozó egyes mutatók más arányban jelennek meg, mint például a HBSC kutatásban, amely a minta eltérő összetételéből is adódhat. A személyiségbeli jellemzőkkel való összefüggéseink viszont megerősítik az előzetes kutatások eredményeit, amennyiben az optimizmus, az önkontroll, és kisebb mértékben az énhatékonyság, elősegítik az egészséget védő ételek fogyasztását, ellenben a pesszimizmus a gyorsételek, az édességek, cukros üdítők és energiaitalok választását alapozza meg. ${ }^{18,29,25}$ Adataink szerint elsősorban a nemkívánatos étkezési magatartás gátlásában van komoly szerepe az önkontrollnak, valamint az optimizmusnak. Továbbá, az utóbbi az énhatékonysággal együtt az egészséges ételek irányába mozdítja el az ételválasztást. A pesszimizmus viszont az érzelmi és társas befolyásolhatóság esélyét növelve fordíthatja a serdülőket a cukros, sok kalóriát és kevés hasznos tápanyagot jelentő ételek felé.

Jelen kutatásunk eredményei, főként annak pilot jellegéből adódóan, néhány limitáció függvényében értékelhetők. Ilyen korlátot jelent az alacsony elemszám, ami főként leíró és kétoldalú kapcsolatokat feltáró adatok elemzését tette lehetővé. Az önkontroll skála további adaptálási és validitási vizsgálatot igényel, a viszonylag alacsonyabb megbízhatósági mutató miatt. További kutatások szükségesek magyarázó modellek (pl. többváltozós regresszióelemzés és mediációs-moderációs elemzések) igazolásához is. Serdülők körében eddig még nem vizsgálták az Étkezési Motiváció Kérdőív ${ }^{10,14}$ által meghatározott motivációkat, így jelen kutatásunkban annyit tudunk megállapítani, hogy az egészséges és az egészségre kockázatos ételek fogyasztásának hátterében eltérő motivációk állnak, amelyek megismerése segíthet megérteni a fiatalok ételválasztási preferenciáit, ami felhasználható az egészségfejlesztési programokban. 


\section{HIVATKOZÁSOK}

${ }^{1}$ Corkins MR, Daniels SR, de Ferranti SD, Golden NH, Kim JH, Magge SN. Nutrition in children and adolescents. Med Clin North Am 2016;100(6):1217-35. doi: 10.1016/j.mcna.2016.06.005

${ }^{2}$ Németh Á., Költő A. (szerk). Egészség és egészségmagatartás iskoláskorban. Az Iskoláskorú gyermekek egészségmagatartása elnevezésű, az Egészségügyi Világszervezettel együttmúködésben megvalósuló nemzetközi kutatás 2014. évi felméréséről készült nemzeti jelentés. Nemzeti Egészségfejlesztési Intézet, Budapest, 2014.

http://mek.oszk.hu/16100/16119/16119.pdf (Elérve: 2017.05.05)

${ }_{3}^{3}$ Pikó B., Keresztes N. Táplálkozáskontroll középiskolások körében: Az étkezési magatartás társas összefüggéseinek nemek szerinti jellegzetességei. Mentálhig Pszichoszom 2008;9(2):149-64. doi: 10.1556/Mentál.9.2008.2.4.

${ }^{4}$ Fitzgibbon ML, Stolley M. Promoting health in an unhealthful environment: Lifestyle challenges for children and adolescents. J Am Diet Assoc 2006;106(4):518-22. doi: 10.16/j.jada.2006.02.029.

${ }^{5}$ Pikó B, Keresztes N. Középiskolás fiatalok étkezési szokásai és ezek hatása a saját táplálkozási magatartás megítélésére. Egészségfejl 2008;49(1-2):9-15.

${ }^{6}$ WHO/FAO: Diet, Nutrition and the Prevention of Chronic Diseases. WHO Technical Report Series 916. World Health Organization, Geneva, 2003. http://www.fao.org/docrep/005/AC911E/AC911E00.HTM (Elérve: 2017.05.05.)

${ }^{7}$ Fülöp N, Szakály Z. Fiatalok táplálkozási szokásai, egészségmagatartása - szekunder kutatás. Élelm Táplál Market 2008;5(1):81-6.

8 KSH. Európai lakossági egészségfelmérés, 2014. Statisztikai Tükör, 2015;29.

${ }^{9}$ Chang FC, Lee CM, Chen PH, Chiu CH, Pan YC, Huang TF. Association of thin-ideal media exposure, body dissatisfaction and disordered eating behaviors among adolescents in Taiwan. Eat Behav 2013;14(3):382-5. doi:

10.1016/j.eatbeh.2013.05.002.

${ }^{10}$ Renner B, Sproesser G, Strohbach S, Schupp HT. Why we eat what we eat. The Eating Motivation Survey (TEMS). Appetite 2012;59(1):117-28. doi: 10.1016/j.appet.2012.04.004

11 Jackson B, Cooper ML, Mintz L, Albino A. Motivations to eat. Scale development and validation. J Res Pers 2003;37:297-318. doi:10.1016/S0092-6566(02)00574-3

12 Pollard J, Kirk SFL, Cade JE. Factors affecting food choice in relation to fruit and vegetable intake. A review. Nutr Res Rev 2002;15:373-87. doi: 10.1079/NRR200244.

${ }^{13}$ Robinson E, Tobias T, Shaw L, Freeman E, Higgs S. Social matching of food intake and the need for social acceptance. Appetite 2011;56:747-52. doi: 10.1016/j.appet.2011.03.001.

${ }^{14}$ Sproesser G. Why we eat what we eat: Psychological influences on eating behavior. Dissertation. Universität Konstanz, Mathematisch-Naturwissenschaftliche Sektion, Fachbereich Psychologie. Konstanz, Germany, 2016. https://pdfs.semanticscholar.org/0ccc/3b0c0b1e83f7f22515dcf49690fa75edbfea.pdf (Elérve: 2017.05.05) ${ }^{15}$ Dernóczy-Polyák A, Keller V. Klaszterképzés evési magatartás alapján - Fókuszban a generációk. Vezetéstud 2017;48(3):28-38.

${ }^{16}$ Verstuyf J, Vansteenkiste M, Soetens B, Soenens B. Motivational dynamics underlying eating regulation in young and adult female dieters: Relationships with healthy eating behaviours and disordered eating symptoms. Psychol Health 2016;31(6):711-29. doi: 10.1080/08870446.2016.1143942

${ }^{17}$ Leblanc V, Bégin C, Corneau L, Dodin S, Lemieux S. Gender differences in dietary intakes: what is the contribution of motivational variables? J Hum Nutr Diet 2015;28(1):37-46. doi: 10.1111/jhn.12213.

18 Tangney JP, Baumeister RF, Boone AL. High self-control predicts good adjustment, less pathology, better grades, and interpersonal success. J Pers 2004;72(2):271-324.

19 Junger M, van Kampen M. Cognitive ability and self-control in relation to dietary habits, physical activity and bodyweight in adolescents. Int J Behav Nutr Phys Act 2010;7(22):1-12. doi:10.1186/1479-5868-7-22.

${ }^{20}$ Adriaanse MA, Kroese FM, Gillebart M, De Ridder DTD. Effortless inhibition: Habit mediates the relation between selfcontrol and unhealthy snack consumption. Front Psychol 2014;5:444 (e-collection). doi: 10.3389/fpsyg.2014.00444.

${ }^{21}$ Galla BM, Duckworth AL. More than resisting temptation: Beneficial habits mediate the relationship between selfcontrol and positive life outcomes. J Pers Social Psychol 2015;109(3):508-25. doi: 10.1037/pspp0000026.

22 Burg J, Lechner L, de Vries H. Psychosocial determinants of fruit and vegetable consumption. Appetite 1995;25(3):285-96. doi: 10.1006/appe.1995.0062.

${ }^{23}$ Parcel GS, Edmundson E, Perry CL, Feldman HA, O'Hara-Tompkins N, Nader PR, Johnson CC, Stone EJ. Measurement of self-efficacy for diet-related behaviors among elementary school children. J Sch Health 1995;65(1):23-7.

${ }^{24}$ Kelloniemi H, Ek E, Laitinen J. Optimism, dietary habits, body mass index, and smoking among young Finnish adults. Appetite 2005;45(2):169-76. doi: 10.1016/j.appet.2005.05.001.

${ }^{25}$ Renner B, Schwarzer R. Social-cognitive factors in health behavior change. In Social Psychological Foundations of Health and Illness, Suls J, Wallston KA. (eds.) Blackwell Publishing, 2003. pp. 169-96. 
${ }^{26}$ Scheier MF, Carver CS. Optimism, coping, and health: Assessment and implications of generalized outcome expectancies. Health Psychol 1985;4:219-47.

27 Bérdi M, Köteles F. Az optimizmus mérése: az Életszemlélet Teszt átdolgozott változatának (LOT-R) pszichometriai jellemzõi hazai mintán. Magy Pszichol Szeml 2010;65:273-94.

${ }^{28}$ Schwarzer R, Jerusalem M. The Generalized Self-Efficacy Scale. In Measures in health psychology: A user's portfolio. Causal and control beliefs, Weinman J, Wright S, Johnston M. (eds.) NFER-NELSON, Windsor, UK, 1995. pp. 35-37.

${ }^{29}$ Kopp M, Schwarzer R, Jerusalem M. Hungarian questionnaire in psychometric scales for cross-cultural self-efficacy research. Zentrale Universitas Druckerei der FU Berlin, 1993.

30 Zhou L, Teng L, Poon PS. Susceptibility to global consumer culture: A three-dimensional scale. Psychol Market 2008;25(4):336-51. doi: 10.1002/mar.20212.

${ }^{31}$ Timlin MT, Pereira MA, Story M, Neumark-Sztainer D. Breakfast eating and weight change in a 5-year prospective analysis of adolescents: Project EAT (Eating Among Teens). Pediatrics 2008;121(3):638-45. doi: 10.1542/peds.20071035. 